\title{
Analysis of the potential socio-economic impact of establishing plantation forestry on rural communities in Sanga district, Niassa province, Mozambique
}

\author{
Jennifer Landry ${ }^{\mathrm{a}, \mathrm{b}}$, Paxie W. Chirwa ${ }^{\mathrm{c}, *}$ \\ a Department of Natural Resources, Forest Management Branch, Fredericton, New Brunswick, Canada \\ b Stellenbosch University, Department of Forestry \& Wood Science, Stellenbosch 7602, South Africa \\ ' University of Pretoria, Faculty of Natural \&' Agricultural Sciences Building, Room 4-11, Lynwood Road, Pretoria 0002, South Africa
}

\section{A R T I C L E I N F O}

\section{Article history:}

Received 8 December 2009

Received in revised form 31 October 2010

Accepted 3 November 2010

\section{Keywords:}

Forest plantations

Afforestation

Socio-economic

FSC standard

Natural resource

Livelihoods

\begin{abstract}
A B S T R A C T
This study assesses the livelihoods of rural households in a proposed green field forestry area located in Sanga district of Niassa province, Mozambique. The livelihood analysis was used to analyze potential socio-economic impacts of introducing forest plantations to rural households located within the proposed afforestation area. The study made use of household interviews, key informant interviews and secondary data. The sustainable livelihoods framework was used in the research process to develop the household questionnaire and to identify livelihood strategies. Data were analyzed using 331 household questionnaires collected throughout the proposed afforestation area in various communities in the study area. Findings from the study indicated that there is minimal wealth gaps between rural households; but that the introduction of the forestry industry and the subsequent employment created thereof may result in larger wealth gaps between wage earning and non-wage earning households. The study further concludes by linking the potential socio-economic impacts with mitigation recommendations that could be harmonized with FSC Standard requirements for forestry companies interested in developing a forest industry in the study area.
\end{abstract}

(c) 2010 Elsevier Ltd. All rights reserved.

\section{Introduction}

\subsection{Background}

In developing countries such as Mozambique, governments view forestry as a means of economic development in rural communities, as it aids economic development by generating revenue (Charnley, 2005) and foreign exchange from exports of forest products or through import substitution (Evans and Turnbull, 2000). Mozambique has a concession area of approximately 400000 ha of state land available for private sector forestry development (Cuellar et al., 2006). These concession areas are delineated in open common lands and lands formerly used for agriculture. Portions of this available land will be leased to suitable private investors that can demonstrate sustainable forest management by reaching annual performance targets and complying with Forest Stewardship Council (FSC) certification standard. Some plantation development has already begun and there has been interest by additional forestry companies in establishing Eucalyptus plantations for the production of pulpwood and solid wood. There are currently five forestry

\footnotetext{
* Corresponding author. Tel.: +27 21420 3213; fax: +27 214204120

E-mail address: paxie.chirwa@up.ac.za (P.W. Chirwa).
}

companies investing in plantation establishment in the Niassa province. However, much of the land available for forestry development is occupied by rural Mozambicans practicing shifting agriculture. According to the latest census done in 2007, Mozambique has a population of 20.5 million people (Instituto Nacional de Estatistica, 2007), approximately $70 \%$ of which live in rural areas (Suca, 2001). The conversion of some 400000 ha of land into forestry plantations has raised concerns amongst various stakeholders regarding the social-economic impacts that may be created (Cuellar et al., 2006).

The introduction of forestry plantations will result in significant land use changes that will impact the livelihoods of rural households. Before implementing such development in Niassa province, it is important for forestry companies to understand the livelihood strategies of rural residents and their reliance on the existing natural resources. Understanding the livelihood strategies of people will help to formulate a forestry establishment program to mitigate any impacts on rural livelihoods, monitor livelihood criterion indicators over time, and identify conservation requirements in order to manage the land in a way to conserve livelihood aspects (such as natural plant species, cultural lands, agricultural resources and water). Currently, there is a lack of information on the socio-economic conditions before and after establishment of forestry plantations (Charnley, 2005). There are few studies that have evaluated socio- 


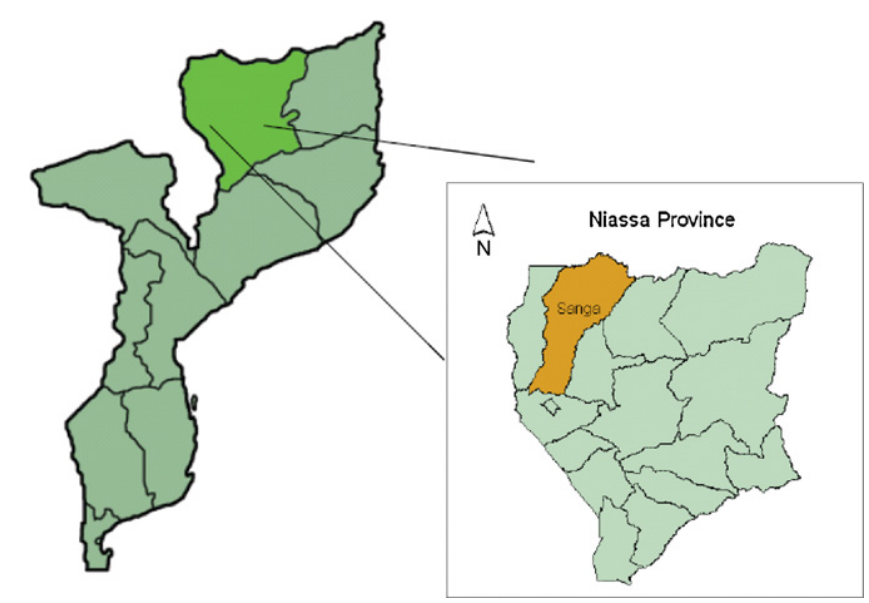

Fig. 1. Diagram showing Mozambique and provinces, with a close-up of the Niassa province of Mozambique, and the study area in Sanga district.

economic impacts which accompany plantation establishment and there is a need to study different modes of plantation industry development and their impacts. In a review by Schirmer (2006) of conflicts over new afforestation programmes around the world, both positive and negative socio-economic factors were identified; most notably revitalization of the rural economy and the environmental impact.

The main aim of this study was therefore to identify and analyze the potential socio-economic impact of a green field forestry project on the livelihoods of rural residents in the rural district of Sanga, in the Niassa province of Mozambique.

\subsection{Study area}

The study area is in Sanga district within the Niassa province of Mozambique (see Fig. 1). The Sanga district is located $60 \mathrm{~km}$ north of the provincial capital city of Lichinga. The northern boundary of the Sanga district is Tanzania. The area of Sanga is $13469 \mathrm{~km}^{2}$ (Ministério da Administração Estatal, 2005) and in 2007 had a population of 56282 inhabitants (Instituto Nacional de Estatistica, 2007). In 1997, the population was 44225 inhabitants with a population density of 4.5 inhabitants per $\mathrm{km}^{2}$ (Ministério da Administração Estatal, 2005). Fig. 2 shows the proposed afforestation area and the location of communities within the Sanga district that were sampled.

Agriculture is the main activity for the residents of the district and is practiced on small plots of land called machambas with an average size of 2.5 ha. Machambas are household plots of land that are used to cultivate crops such as cassava, maize, beans, and potatoes. Families within the sampled area farm an average of 1.6 machambas. Wet machambas, commonly referred to as dambos, are also family plots of land located within wetlands or dambos. In these dambos, households cultivate crops such as tomatoes and green leafy vegetables. Nearby Miombo woodlands are primarily used for hunting, wood (energy, construction materials, wood products), charcoal production, food gathering and as a source for medicinal plants. Rivers in the study area are used for fishing and as a water source for consumption and cleaning.

\section{Methodology}

\subsection{Survey and sampling procedure}

The study was conducted in the Sanga district located within the Niassa province of Mozambique. The area was selected since

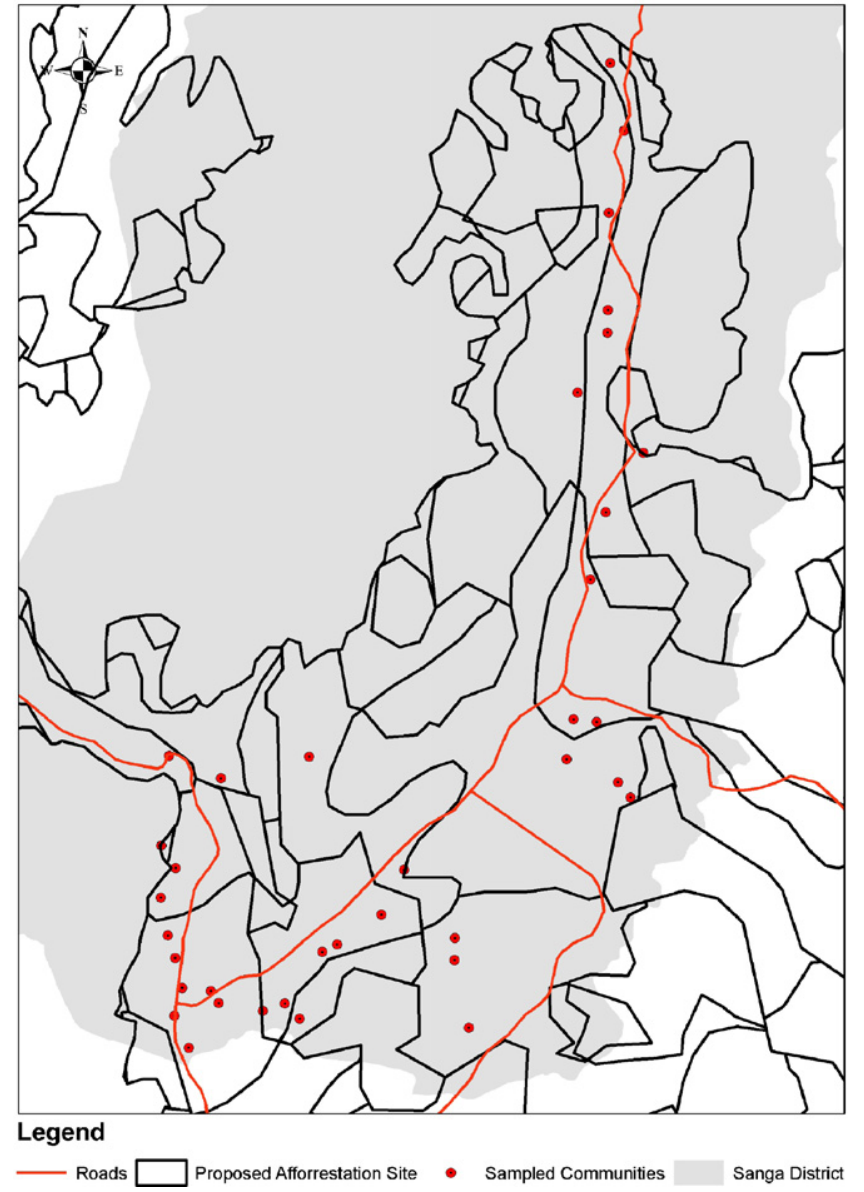

Fig. 2. Map showing the sampled communities within the proposed afforestation area in Sanga district.

the majority of the proposed plantation area falls within this district. There were approximately 33 villages or communities and interviews were conducted in all of the communities. A total of 338 households were interviewed by estimating a $5 \%$ household sample in each of the communities in Sanga. A 5\% sample is considered sufficient in survey research (Bartlett et al., 2001). Household livelihoods in the rural communities were evaluated using the sustainable livelihoods framework which helped to identify the household survey questions (Place et al., 2003). The household questionnaire collected general household information and was designed to assess the socio-economic position of households within the community, their livelihood strategy, natural resource use, household vulnerability, and their perceptions of the impacts of introducing plantations in their communities. Questions were formulated to collect household data to assess their asset or capital status in terms of natural, physical, human, financial and social capitals. Questions were also formulated to understand how households cope with shocks, trends, and seasonality. In addition to a household survey, key informant interviews were conducted with individuals with specialized knowledge, such as government representatives, NGOs, private industries, and religious organizations (Adato and Meinzen-Dick, 2002). These semi-structured interviews were used to solicit local knowledge, opinions, and views of local livelihoods. Key informant interviewees were also asked how they thought forestry would impact local rural residents and what mitigation measures would be required. Key informant interviewees were purposively selected and had the ability to communicate in English or with a translator. 


\subsection{Data analysis}

Household survey data were statistically analyzed using Statistica 8 (StatSoft Inc., 1984-2008). Basic descriptive statistics and frequency tables were used to summarize the answers to each of the household survey questions. Using more applied statistical analysis, comparative relationships between different household variables and wealth categories were analyzed in order to understand different livelihood strategies and contributors to wealth. Three wealth categories (low, medium and high) were defined by a numerical ranking of wealth indicators. The wealth indicators used in this analysis were area of household land holdings, type and size of housing and household physical assets. When analyzing the wealth categories (see Ellis, 2003) three statistical tests were used; Maximum likelihood Chi-square (Sokal and Rohlf, 1994), Non-parametric Kruskal-Wallis tests (Kruskal and Wallis, 1952), and Non-parametric Mann-Whitney tests (Mann and Whitney, 1947). Each of the statistical tests was considered significant at $p \leq 0.05$.

\section{Results}

\subsection{General household information}

Males headed $91 \%$ of the households in the sample population. The wealth status categorization of households showed that most households ( $82 \%$ ) were classified as medium, followed by the high (10\%) and low (9\%). Female headed households occurred significantly $(p \leq 0.05)$ more frequently in the low wealth category than male headed households. The average number of people in a household was 6 and the average age of all sampled household members was 20; with the majority of the sample population (52\%) under the age of 15 years. The average age of the head of household was 42 with mean education level of grade 5 . Overall, $47 \%$ of households reported that their children were attending school.

\subsection{Use of natural resources}

\subsubsection{Land uses}

The land classes were identified through interviews with key informants and field visits with local experts. Various land classes were observed during the study. Households were asked to rank the importance of these land classes with respect to their livelihoods. Natural forests (implying old growth Miombo woodlands) were ranked the most important land class overall, followed by sandy soils, machamba land, old abandoned machambas, river zones, wet machambas (including dambos), grasslands, and deforested areas (see Table 1). Ranking of important land classes was consistent

Table 1

Household ranking of different land classification to indicate importance of land in Sanga district.

\begin{tabular}{llc}
\hline Land classifications & $\begin{array}{l}\text { Rankinga } \\
\text { (mean (SD) }\end{array}$ & $\begin{array}{l}\text { Number of } \\
\text { households }\end{array}$ \\
\hline Natural forest & $2.76(0.53)$ & 290 \\
Sandy soils & $2.00(0.85)$ & 12 \\
Machambas & $1.87(0.67)$ & 217 \\
Old machambas & $1.81(0.69)$ & 74 \\
River zones & $1.70(0.71)$ & 166 \\
Dambos or wet machambas & $1.53(0.67)$ & 151 \\
Grasslands & $1.43(0.65)$ & 37 \\
Deforested areas & $1.41(0.68)$ & 46 \\
\hline
\end{tabular}

a Ranked 1-3, with the highest ranking mean signifying the most important land classifications; $\mathrm{SD}=$ standard deviation.
Table 2

Household ranking of lands most willing to be given up for afforestation in Sanga district.

\begin{tabular}{llc}
\hline Land classifications & $\begin{array}{l}\text { Ranking } \\
(\text { mean }(S D))\end{array}$ & $\begin{array}{l}\text { Number of } \\
\text { households }\end{array}$ \\
\hline Other (not willing to give up any lands) & $2.58(0.79)$ & 12 \\
Old machambas & $2.55(0.74)$ & 244 \\
Natural forest & $2.47(0.81)$ & 54 \\
Machambas & $2.24(0.75)$ & 122 \\
River zones & $1.87(0.58)$ & 54 \\
Deforested areas & $1.75(0.67)$ & 142 \\
Grasslands & $1.74(0.61)$ & 114 \\
Sandy soils & $1.53(0.72)$ & 189 \\
Dambo or wet machambas & $1.47(0.69)$ & 47 \\
\hline
\end{tabular}

a Ranked 1-3, with the highest ranking mean signifying the lands households are least willing to give up; $\mathrm{SD}=$ standard deviation.

across wealth categories, with the exception of dambos and/or wet machambas in medium wealth households. Wet machambas were significantly $(p \leq 0.05)$ more important for medium wealth households than low or high wealth households.

The land class that households were most willing to give up for forestry development (Table 2) was old ${ }^{1}$ machambas and Miombo forest. There were 12 households that responded very strongly against forestry development and land use changes. There were, however, no significant differences in responses across wealth categories.

\subsubsection{Natural forest use}

On average, 2 people in each household are responsible for the daily collection of firewood, and each household spends about $3.6 \mathrm{~h}$ per day collecting firewood. The majority of households (91\%) collect their own firewood, $5 \%$ buy and collect firewood, $3 \%$ use charcoal rather than firewood, and $1 \%$ buy all of their firewood. Wealth categories showed no significant difference in how firewood is acquired by the household or in the amount of time spent collecting firewood.

A few households (41\%) reported the use of traditional medicines and the wealth of households did not significantly contribute to traditional plant use. Household members collect their own plants for medicine on average 196 times per year or 3.8 times per week. Overall, households that use traditional plants acquire their plants by buying (55\%), collecting (28\%), and buying and collecting (16\%). The majority of households (59\%) reported that they do not use traditional medicines. Wealth status did not significantly influence the decision on the use of traditional plants for medicine.

\subsection{Forestry awareness, participation willingness and perceptions}

Households were asked if they were aware of forestry development plans for the area, and 39.6\% of the households answered 'yes' that they were aware, and the remaining $60.4 \%$ answered 'no' that they were not aware of such plans. Those households that answered 'yes' heard about forestry development plans from community members (21.4\%), local government (11.5\%), public consultations (3.9\%), school $(0.3 \%)$, or were not sure $(1.2 \%)$.

Overall, $87 \%$ of the households would be willing to plant trees on their own land for a forestry company while $11.8 \%$ were not willing and $1.2 \%$ were not certain. The willing households had on average 2.1 ha of land available for planting trees based on a rough estimation of their own lands. High and medium wealth households had

1 Old machambas refers to the abandoned agricultural plots of land which are no longer used. 
Table 3

Perception of the greatest benefit that forestry will bring to communities in the Sanga district.

\begin{tabular}{ll}
\hline Community benefits & $\begin{array}{l}\text { Frequency of } \\
\text { households (\%) }\end{array}$ \\
\hline Employment & 64.6 \\
More money for local markets & 14.2 \\
No benefits to community & 8.2 \\
Better social services (schools, hospitals, etc.) & 7.5 \\
Better roads & 4.5 \\
More wood available & 0.3 \\
Shade from trees & 0.3 \\
Minimize erosion & 0.3 \\
\hline
\end{tabular}

significantly $(p \leq 0.05)$ more land available for commercial forestry than low wealth households.

The households indicated that they would establish the plantations near or in the community (34.7\%), on old machambas $(25.9 \%)$, on machambas (28.7\%), on sandy soils (1.2\%) and in river zones $(0.6 \%)$ while $0.3 \%$ were not sure where to plant. Some either had no land to plant $(0.6 \%)$ or did not respond (7.8\%). Wealth status had no significant impact on the willingness of a household to plant trees for commercial forestry or on where households would establish the plantations.

\subsection{Perceived benefits and negative impact of forestry on community}

Households were asked a series of questions in order to understand their perceptions of forestry and how they thought forestry would benefit and impact their community. In the case of all perception responses, household wealth did not significantly influence perception responses. Employment (64.6\%) was the most common community benefit cited by households (Table 3). Many households (48.3\%) felt that forestry would not result in any impact on their communities (Table 4). The most frequent concern expressed by households was that family members would be working outside the home (24.5\%) and would therefore not be available to perform current household duties.

\subsection{Perceived benefits and impacts of forestry employment on family}

The most common response to household benefits of employment within a forestry company was income (57.4\%) and education for their children (27.8\%) (Table 5). Many households (54.4\%) felt that forestry would not result in any negative impacts to their household except that fewer family members would be available to perform household duties (16.6\%) (Table 6).

For those households hypothetically not directly employed by a forestry company, the creation of indirect employment (35.0\%) and

\section{Table 4}

Perception of the greatest negative impact forestry will have on the communities in the Sanga district.

\begin{tabular}{ll}
\hline Community impacts & $\begin{array}{l}\text { Frequency of } \\
\text { households (\%) }\end{array}$ \\
\hline No impacts & 48.3 \\
Family members working outside of home & 24.5 \\
Less resources available & 7.8 \\
Less land for agriculture & 6.6 \\
More traffic on roads & 5.4 \\
Less water available & 2.4 \\
Immigrants (increase in population) & 2.4 \\
Land restrictions/less access to land & 1.2 \\
No opinion & 0.9
\end{tabular}

Table 5

Perceptions of benefits that a forestry company can bring to the family in employment in Sanga district.

\begin{tabular}{ll}
\hline Family benefits for forestry workers & $\begin{array}{l}\text { Frequency of } \\
\text { households (\%) }\end{array}$ \\
\hline Income & 57.4 \\
Education for children & 27.8 \\
Food security & 9.7 \\
No benefit to family & 3.3 \\
Able to have a better house & 1.2 \\
New business & 0.3 \\
Will have a better life & 0.3 \\
\hline
\end{tabular}

Table 6

Perceptions of negative impact on the family if they were employed by a forestry company in Sanga district.

\begin{tabular}{ll}
\hline Family impacts for forestry workers & $\begin{array}{l}\text { Frequency of } \\
\text { households (\%) }\end{array}$ \\
\hline No impact on family & 54.4 \\
Less family members to perform household duties & 16.6 \\
Less land for agriculture & 15.4 \\
Availability of resources & 7.8 \\
Less access to land & 3.3 \\
Less water available & 1.2 \\
Immigrants (increase in population) & 1.2 \\
\hline
\end{tabular}

better infrastructure (38.4\%) were the two most common responses to the household benefits (Table 7), but many (51.3\%) of the households thought that forestry would have no impact on the family (Table 8). Interestingly, the number of households that thought there would be no benefits increased from $3.3 \%$ for those employed (Table 5) to $19.9 \%$ for those not employed (Table 7 ) by a forestry company.

\subsection{Perceived impacts of forestry on culture and tradition}

During the interview, $80.9 \%$ of the households approved that females could be working away from the home in a forestry plan-

Table 7

Perceptions of benefits for the family if they were not employed by a forestry company in Sanga district.

\begin{tabular}{ll}
\hline Family benefits for non forestry workers & $\begin{array}{l}\text { Frequency of } \\
\text { households (\%) }\end{array}$ \\
\hline Creation of indirect employment & 35.0 \\
Better infrastructure & 38.4 \\
No benefits to family & 19.9 \\
Availability of wood & 4.8 \\
No opinion/not sure & 0.6 \\
Generally will bring good benefits & 0.6 \\
More water available & 0.3 \\
\hline
\end{tabular}

Table 8

Perceptions of impacts on the family if they were not employed by a forestry company in Sanga district.

\begin{tabular}{ll}
\hline Family impacts for non forestry workers & $\begin{array}{l}\text { Frequency of } \\
\text { households (\%) }\end{array}$ \\
\hline No impact on family & 51.3 \\
Less available resources & 11.5 \\
Less land for agriculture & 10.3 \\
More traffic on roads & 9.9 \\
Immigrants (increase in population) & 5.4 \\
Less water availability & 5.1 \\
Land restrictions, less access to lands & 3.9 \\
No benefits to family & 2.1 \\
No opinion & 0.3 \\
\hline
\end{tabular}


Table 9

Perception on the negative impact afforestation may have on the local culture and tradition in Sanga district.

\begin{tabular}{ll}
\hline Impacts on local culture and tradition & $\begin{array}{l}\text { Frequency of } \\
\text { households (\%) }\end{array}$ \\
\hline Change in traditional land use & 29.3 \\
No say in plantation management & 22.3 \\
Change to family by members working outside the home & 14.5 \\
Change to religious customs & 13.9 \\
Outsiders influencing local culture and traditions & 13.0 \\
No impact & 6.3 \\
Did not respond & 0.9 \\
Environmental impacts & 0.3 \\
\hline
\end{tabular}

Table 10

The perception of households of the impacts of introduction of plantation forestry on land availability within Sanga district.

\begin{tabular}{ll}
\hline Impact on land availability & $\begin{array}{l}\text { Frequency of } \\
\text { households (\%) }\end{array}$ \\
\hline Enough land for everyone & 67.1 \\
Not enough land & 21.7 \\
Will be the same & 10.3 \\
Did not respond & 0.9 \\
\hline
\end{tabular}

tation but $9.7 \%$ said they did not want females to be working while 9.4\% did not have an opinion.

Change in traditional land use was the most common concern (29.3\%) expressed by households on perceived impacts of introducing forestry on local culture and traditions, followed by 'no say' in plantation management (22.3\%) (Table 9 ). Only $6.3 \%$ of the households thought that forestry would have no impact on their local culture and traditions.

\subsection{Impacts on land availability and water}

The majority of households $(67.1 \%)$ perceived that there would be enough land available for everyone (plantations and rural residents) but $21.7 \%$ thought that there was not enough land for everyone (Table 10). The majority of households (82.2\%) felt that forestry would result in an increase in available water (Table 11).

\subsection{Key informant interviews}

During key informant interviews, informants were asked informal questions regarding the introduction of forestry in the study area. Eight interviews were held with individuals from health and economic development non government organizations, agriculture industry (Tobacco), provincial government, local social scientist, local professional forester, and local education professional. The questions they were asked were formulated to gain an understanding of the livelihood strategies of rural residents. Interviews were held before the questionnaire surveys, however further discussions

\section{Table 11}

The perception of households of the impacts of introduction of plantation forestry on water availability within Sanga district.

\begin{tabular}{ll}
\hline Impact on water availability & $\begin{array}{l}\text { Frequency of } \\
\text { households (\%) }\end{array}$ \\
\hline Increase water & 82.2 \\
Decrease water & 6.9 \\
Will be the same & 9.1 \\
No opinion & 0.3 \\
Did not respond & 1.5 \\
\hline
\end{tabular}

were held after the interviews with a few individuals to discuss field observations and preliminary findings. Key informant interviews helped to formulate relevant household interview questions and to apply the correct wording. In addition, key informant interviews were used to solicit input from individuals familiar with rural livelihoods on what potential impacts may be created, and what challenges a forestry company may face.

\subsubsection{Potential impacts}

Everyone that was interviewed thought that forestry plantations would create positive impacts 'if the company put in place adequate programs to assist rural households with land use changes'. Key informants identified the following positive impacts: employment (both direct and indirect), economic diversification, improved infrastructure and health care within the communities and city of Lichinga, and better education.

\subsubsection{Potential forestry development challenges}

The informants identified a number of challenges that forestry companies may be faced with when initiating forestry plantations. The main challenges that were identified can be summarized as follows:

- Education - currently the rural residents are not well educated and very few would be able to perform duties beyond manual labor which is usually seasonal employment. Currently residents will not be able to take on professional level roles that would allow them to work full time. Many families begin the school year by sending their children to school, but when the planting season comes the children in many cases need to be taken out of school to help cultivate the land. The school schedule is not flexible to accommodate for this and children are unable to complete their school. There are also some communities that do not have schools making it impossible for children to get an education. Many rural residents do not educate their daughters as in their matrilineal culture, the daughter will have to stay with the family even after they get married. If their daughters are educated there is a fear that they will leave and there will be no one to stay and take care of the family.

- Shifting agriculture - households practice shifting agriculture and will use plots of land for short periods of time and then move to a new plot. Apparently once agriculture plots are abandoned, farmers do not return. Forestry plantations will limit their ability to shift and may create land conflicts. Many households can only manage small plots of land due to limited resources (i.e. people to work the land, tools).

- Culture - people living in the rural communities are very traditional and follow practices that may hinder private sector development. For example, the people have been practicing their semi-nomadic way of life for generations. Many households practice polygamy and children at the age of pubescence undergo circumcision rituals and begin their preparatory journey to adulthood. It is at this time that many girls are taken out of school. Traditional leaders in the communities and districts continue to play a significant role. Outsiders must get approval from traditional leaders before pursuing any activities in the communities. In addition, many people are not accustomed to working under the conditions and expectations of others.

- Bush fires - during the dry season there are many bush fires that are started by people throughout the area. Some of the reasons fires are started are pest control, hunting, to herd the animals in a particular direction, to clear land, and others for no apparent reason. The issue of bush fires was raised by informants since they thought it possible that rural residents may use fire during times of conflict with a Forestry Company. 


\section{Discussion}

\subsection{Natural resource use}

Rural livelihood strategies are typically heavily reliant on natural resources (Scoones, 1998) and for the households in this study this statement was certainly found to be true. The natural forestlands were ranked the most important land class and are used for a variety of household activities such as fuelwood, food collection, hunting, harvesting timber for construction, charcoal, and traditional medicines. During the hunger season (summer months of December to March) the natural forests are essential for rural livelihood strategies since they are an important source of food and for resources to generate an income. This safety net feature of the Miombo woodlands or forestland has also been highlighted by others (see Akinnifesi et al., 2008; Chirwa et al., 2008). Natural forestlands are cleared and machambas are established and used for both subsistence and as the primary source of income for households.

While machambas were ranked as important to households for reasons already described, old machambas that are left abandoned also play an important role in rural livelihoods. Important tree species such as mango, banana, jujube (Ziziphus mauritania), peach, orange, and papaya that were left uncut continue to exist and are fruit producing trees used for consumption and income. Although important, households were most willing to give old machambas up for forestry development. It is in these old machambas where forestry developments is planned as it is assumed it will have the least impact on rural households; and are acceptable areas for plantations under the international Forest Stewardship Council (FSC) standard (FSC, 1996). Notwithstanding, several studies have reported rapid development of Miombo regrowth in abandoned cleared plots in many parts of the Miombo ecoregion (Boaler and Sciwale, 1966; Strang, 1974; Geldenhuys, 2005; Syampungani, 2008). In addition, introduction of forestry in these areas will impact on the availability of fruits to rural households as discussed earlier.

Sandy soils were ranked as the second most important land class albeit ranked highly only by 12 households (see Table 1 ). Sandy soils are not normally desirable lands for agriculture but can be sources for different trees for wood, fruits, and plants for food and medicine, and for some households farming. River zones are used for fishing, bathing, cleaning laundry, a water source and for recreation by nearby rural households. Dambos or wet machambas are important areas for vegetable cultivation and these areas are used for longer periods of time (sometimes more than 10 years). These areas are wetter and have richer soils which allow households to cultivate crops throughout the year. In the event of forest development, wetlands are important conservation priorities in FSC; and therefore will require protection and conservation to achieve third party certification.

Medium wealth households ranked dambos significantly $(p \leq 0.05)$ more importantly than high and low wealth households. Medium wealth households made up the majority of the study sample population, and tended to have more assets (e.g. labor, land, seeds, tools) compared to low wealth households to manage dambos (Landry, 2009). Conversely, high wealth households have the resources to manage dambos but appear not to do so. It is conceivable that high wealth households did not rank them as important since they do not depend on them as much for food security. At this time, there are no forest activity plans for dambos, river zones and sandy soils. However, these may be impacted indirectly in the event that households become more dependent on them in the consequence of a reduction in natural resources.

Grasslands and deforested areas were not considered as valuable as other natural resources. Grasslands are most notably used for thatch grass and households cut grass during the dry season. Field observations indicated that many people also use open lands in addition to old machambas, and within the communities and near homes for brick making. Deforested areas were ranked the least important, but apparently are the future sites of machambas. It can be speculated that households ranked this land type low since their perceptions regarding land availability in the study indicated that they thought there was sufficient land for everyone; and could therefore access more machamba land by harvesting marginal forestland. Thus, even though land is currently bare, it does not mean that it is not valuable to rural households. It is also possible that households will only realize their importance when the lands are no longer available as a result of afforestation. Hence, there is a strong possibility that planting of forestry plantations, even on bare lands, will create impacts to the households who may want the land in the immediate future.

For purposes of new green field projects, grasslands, like river zones and natural forest, are considered high conservation value areas and there are currently no plans to establish plantations in these areas (Ferraz and Munslow, 1999).

\subsection{Potential socio-economic impacts of introducing forestry industry}

Household benefits and perceptions on negative impact of introducing forest industry were assessed during the study. The most common benefit that was conveyed by households was employment and the most common perceived family benefit for non forestry workers was better infrastructure (38.4\%). Hence, it can be implied that there is an expectation in the community that forestry investments will encourage development in the way of better health care, education, roads, electricity, etc. (Tschirley and Benfica, 2001).

The households conveyed a strong willingness to participate in planting trees on their own land for forestry companies, with $87 \%$ of the households willing to plant an average of 2.1 ha of land. High and medium wealth households had more land that they were willing to plant than low income households. Therefore, low wealth households would require more assistance in order to ensure that they can have the same opportunities and benefits as wealthier households. The majority of households reported that they would like to establish such plantations in or near the community on abandoned machambas. Based on these findings, the prospect of the introduction of an out-grower scheme in the study area by the forestry companies appears quite promising. An out-grower scheme would allow interested households to plant and maintain forest plantations on their household and/or community land (Race and Desmond, 2001).

\subsection{Land use change and land availability}

The proposed forestry plan for the area is to establish commercial forestry plantations of Eucalypts and Pines. Investing forestry companies will be required under the national land use agreement to obtain Forest Stewardship Council (FSC) certification. Under the requirements of the FSC standard, forestry companies will not be able to convert ${ }^{2}$ natural Miombo woodlands to plantations (FSC, 1996). Therefore, plantations will be established on already deforested lands; primarily in abandoned machambas. However, there are reports that plantations have been established in existing

\footnotetext{
2 FSC Principle 10.9 (Plantation Conversion): P̈lantations established in areas converted from natural forests (after November 1994) normally shall not qualify for certification.
} 
machambas, thus requiring households to relocate their machambas to other areas. This was what a forestry company in the study area did, and in a recent media case the company relocated 13 families in Sanga from their current machamba land to another area (Aide, 2009). The most obvious and potentially devastating impacts will be those as a result of land use changes, from household agriculture to forestry plantations. Impacts of insufficient community agricultural land may include migration to other areas and further clearing of high conservation value Miombo woodlands, land conflicts, damage to plantations by fire or other means, crop theft, increased reliance on other available resources and marginal lands, and selling assets and/or crops (Kumar et al., 2000; Tonts et al., 2001; Heaton, 2005; Maung and Yamamoto, 2008; Clement and Amezaga, 2009). Non-agricultural income diversification can help households cope with less land availability (Bryceson, 2002) and reduce rural poverty (World Bank, 2008).

Households in general had little concern regarding land availability, and the majority of households (67.1\%) reported that there would be enough land available for everyone; for forestry and agriculture (see Table 10). Households generally expressed anticipation for forestry to be introduced in the area. The fact that people seemed so anxious for forestry development to begin may have influenced their perception and/or responses; thus making them reluctant to express any negative concerns that they had in fear that the project would be cancelled.

Current customary land tenure is weighted towards the communities having the final say and granting approval to activities on their settled land. The land law recognizes traditional land ownership and the rights of rural residents to use and occupy land. Hence communities within the study area treat the forestry concession areas as belonging to their communities. However, in Mozambique the state is ultimately responsible for state land and the state delegates land to government administrations, local communities and the private sector (Nhantumbo et al., 2001). The issues regarding land tenure in Mozambique may have major implications to the success of a green field forestry project in the area, and the boundaries between land rights and authorities of government and communities do not appear to be clearly defined.

\subsection{Water and natural resource availability}

Most of the households (82.2\%) thought that forestry plantations would increase water availability (Table 11). There is a belief that trees create water and colder temperatures, which was pointed out during household interviews. This is contrary to beliefs in many other countries and forestry regions. In these other areas the perception is that forestry plantations deplete water resources and cause drought (Ramadhani et al., 2002). Forestry plantations require water all year round and regardless of the local acceptance of plantations, the forestry companies will have to take a proactive and responsible approach and begin water monitoring studies and ensure water levels for neighboring farms are adequate. The most important and potential impact of forestry on natural forests and natural resources is the conservation of existing Miombo woodlands. Measures may need to be put in place to conserve them from further clearing. To promote ecological and economic stability in the community lands or common pool resources (CPR), community based natural resource management would be the most viable option (Adhikari et al., 2004).

In addition, livelihood opportunities within the forestry plantations must also be investigated. Perhaps there will be opportunities for communities to use plantations for non-forestry uses such as honey production, charcoal production, fuelwood, fodder for livestock (Davidson, 1995), and mushroom cultivation (Buyck, 2008).

\subsection{Cultural and social impacts}

There is concern that the introduction of forestry and the availability of employment in the area will result in an influx of migrant workers and/or outsiders who may take available jobs and influence their culture and traditions. Given the current low availability of skilled labor, outsiders will be needed to perform management and technical duties. The majority of rural people in the area at this time will only be able to carry out manual labor duties. It is possible that migrant workers may arrive from surrounding regions in search of manual labor jobs (Cramer and Pontara, 1998). The rural residents are very traditional and there is concern that outsiders and migrant workers may disrupt their customs such as religious traditions, community leadership structures, marriage and family customs and circumcision rituals.

Forestry may influence gender relations, since employment by a forestry company will allow women equal opportunities (i.e. positions and salary). In Mozambique, women seek a husband for financial security (Pontara, 2001). Therefore it can be implied that as women gain more financial independence, this may also influence the number of female headed households in the future and there may be more family separations or women choosing not to get married. In households where women are working, traditional roles may change and families with young girls may see advantages to allowing their daughters to continue their education and remain in school. In general, with respect to childhood education, the creation of other livelihood opportunities may help change the attitudes of households toward education, i.e. making education for their children more of a priority and a possibility with increased income.

The majority of households thought that the greatest benefits of forestry to their families and the community would be the creation of employment and income, both directly and indirectly. However, the creation of employment and income may create cultural and social impacts. Negative social and cultural impacts that may develop include prostitution, increased alcohol consumption, a rise in crime rates and gender equity (Forestal Oriental, 2006), changes to traditional family structures (Cramer and Pontara, 1998), and a greater wealth gap between households (Tschirley and Benfica, 2001). Culturally, communities customarily operate under a traditional leadership system where each community has appointed leaders who make the decisions. There is concern that the communities will have no control or say in forestry company decisions. If communities feel powerless on their own land there will be a risk of land disputes and conflict.

\section{Conclusion and recommendations}

\subsection{Conclusion}

Forestry will have both positive and negative impacts on rural households in the proposed afforestation area, and it will be important that these impacts are monitored and reported on as the green field projects progress. The review and analysis of this study has resulted in the formulation of recommendations to help offset any negative impacts that may transpire as a result of forestry development. It is important to note that recommendations may require modifications as a result of continuous monitoring. Monitoring should proactively identify any unforeseen socio-economic impacts. In addition, most of the recommendations presented here meet international FSC certification requirements (FSC, 1996). Hence, by implementing the recommendations outlined below, any Forestry Company investing in development will also meet applicable FSC standard criteria.

The study concluded that although households are categorized into three wealth categories, there are minimal wealth gaps 
between these wealth categories. Most of the household livelihoods depend heavily on subsistence agriculture and marginal lands (natural forest, rivers, wet areas, grasslands). There is a possibility that employment opportunities created by forestry will create larger wealth gaps between wealth classes due to disparities between wage earning households and non-wage earning households.

Based on the response from the study area, it was concluded that the most commonly perceived positive socio-economic benefits of forest plantations were creation of employment and better infrastructure (e.g. schools, health care services and roads) while the adverse socio-economic impacts were land use change and land availability, water and natural resource availability, less household labor for agriculture and livelihood activities, increase in traffic on roads, and social and cultural changes.

\subsection{Recommendations for mitigating adverse socio-economic impacts}

The information from this study serves as base line data to monitor socio-economic impacts as forestry developments continue. It is hoped that poverty alleviation and rural development will be better articulated in the future if the following recommended measures are adopted by investors initiating forestry development in the study area and other areas with the same socio-economic dynamics.

\subsubsection{Recommendation 1: monitoring program}

Establishing a monitoring program that periodically evaluates household socio-economic status, livelihood strategies, and forestry perceptions is critical throughout the implementation process of forestry. The methodology used in this study should serve as a useful guide in collecting household data. However, adjustments to wealth indicators and forestry perception questions will be necessary as development continues in order to adequately evaluate socio-economic status, assets, and wealth gaps. Future household surveys should obtain more information regarding salaries acquired from activities in order to analyze wealth gaps between households. In addition, monitoring as development progresses should also include an assessment of infrastructure development (market access, roads, health care, schools), and any social issues that may arise. Such a monitoring program should indicate positive and negative impacts from forestry and the need for additional mitigation programs.

\subsubsection{Recommendation 2: partnerships for livelihood \\ diversification and agriculture intensification}

The purpose would be to promote livelihood diversification and agriculture intensification in the communities and to help rural households become less dependent on agriculture as their primary livelihood activity. Intensification will also promote more sustainable agricultural land use by keeping farmers from having to migrate to other machambas every 2-3 years and/or the need to move to another community to access more land. Changing household agricultural practices will be critical to the success of a green field project, especially if as mentioned in the discussion, households do in fact return to abandoned machambas after several years. If households continue to practice shifting agriculture the Miombo woodlands will continue to decline as a result of deforestation for arable land. Livelihood diversification beyond forestry and small holder agriculture (household machambas) would be valuable particularly in helping disadvantaged households not directly employed in forestry. These potentially disadvantaged households will be particularly susceptible to negative impacts associated with land use change and forestry (Tonts et al., 2001).
Promotion of these livelihood initiatives can be accomplished by forestry companies becoming actively engaged in supporting and developing partnerships with local NGO's, state agencies, and local communities through existing community based natural resource management programs (CBNRM) and agriculture assistance programs (Salomão and Matose, 2007). CBNRM programs will help rural households pursue other livelihood activities to help diversify their livelihoods. In addition to CBNRM programs, the forestry company can promote diversification and indirect employment in the community by investigating livelihood opportunities within plantation resources (charcoal production, livestock grazing, honey production, and mushroom cultivation), launching a third party out-grower scheme (Race and Desmond, 2001), and initiating a community advisory group to build relationships with local communities. The community advisory groups will allow local communities the opportunity to hear directly from the forestry company about management plans and communities will also be given the opportunity to have their voices heard.

Agriculture intensification practices can be promoted by supporting and establishing partnerships with NGO's and state agencies in the area and government agriculture departments. These organizations are carrying out various programs to educate farmers and provide assistance to farmers to promote agriculture intensification and diversification of livelihoods (Irish Aid, 2007; Dougnac, 2008; Manhiça, 2008).

\subsubsection{Recommendation 3: employment equity and local labor preferences}

Some of the case studies in the literature noted that employment creation lead to wealth gaps and that the disadvantaged households were not able to benefit from rural development due to inaccessibility of employment opportunities (Tonts et al., 2001; Tschirley and Benfica, 2001). In these case studies, the social elite or wealthier households were the people getting employed. In addition, in Mozambique, more labor opportunities are offered to males than females, and when females obtain employment their wages are normally less than that of men (Cramer and Pontara, 1998). In order to promote positive benefits to all levels of society, the forestry company should hire across all socio-economic and gender classes and provide assistance to employees and their families to allow them to work away from their home (e.g. childcare, access to food markets for purchase, tools and/or labor to reduce time spent in household machambas).

Households were concerned with the possible influx of immigrant workers coming into their communities seeking work opportunities. To mitigate this, preference should be given to local labor especially when recruiting unskilled manual labor and providing training to currently unskilled labor.

\subsubsection{Recommendation 4: conflict resolution}

Current land tenure is under customary agreements whereby the approval of land use changes for private sector use is granted by communities and local governments. What will happen in the event that communities no longer want to grant plantation land use? Will the government grant approval regardless? With current land tenure and laws, it is conceivable that land conflicts will arise. When households are required to cope with land use changes and associated impacts (e.g. limited access or availability of resources, feelings of powerlessness over communal lands, cultural changes) a possible coping mechanism that may arise is land conflicts. Affected communities and households may resort to non-violent and violent conflict when they become vulnerable to such shocks and stresses. Therefore, it is recommended that any forestry company involved should ensure that customary agreements are respected, an agreed upon approval process is in place with all parties involved, and 
a conflict resolution strategy is prepared. Finding a harmonious balance between the various land uses in the study area will most likely be the most challenging aspect of the green field project and will require much consultation, research, and effort.

\subsubsection{Recommendation 5: health and safety}

In the proposed afforestation area, there are numerous health concerns (e.g. HIV, tuberculosis, malnutrition, malaria). It is recommended that any forestry company involved should promote health and wellness with their employees and their families by offering health and nutrition education, medical check-ups and treatment, and implement measures to protect employees from malaria. The forestry company should also promote health and wellness in the communities by collaborating with local health authorities and NGO's. In the study, households relayed concerns regarding increased road traffic. Public safety measures should therefore be implemented to ensure company transport does not jeopardize their safety.

\subsubsection{Recommendation 6: conservation and resource availability}

It was discussed that forestry development may create more pressure on existing natural resources, in particular Miombo woodlands. Households may be forced to harvest Miombo woodlands to open up new arable lands for their crops and possibly opportunities for plantations for outgrower schemes. Although Miombo woodlands will not be directly impacted by afforestation as they will not be converted into plantations, it is recommended that any forestry company involved should implement measures to help conserve natural resources (including Miombo woodlands) in accordance with Wildlife and Forestry laws by participating in local conservation efforts with local communities, associations and private sector. Ideally, if farmers could use agricultural land more sustainability by applying fertilizers and using the same land continuously (intensification) rather than abandoning machambas and further clearing Miombo woodlands for new agricultural land, it would help conserve these woodlands. However, changing agricultural practices takes time and to begin a Green field project today, Miombo conservation programs will be required, and monitoring of further deforestation as a result of plantations must be put in place.

In addition, this study has identified the following conservation priorities: fruit bearing trees, community water sources, and areas of cultural significance (e.g. burial sites). Lands that have cultural significance should be mapped out with the assistance of the communities and the forestry company involved should conserve them. Fruit trees remaining in planned afforestation areas will most likely need to be harvested. The company should therefore work with the communities to develop a program to mitigate fruit tree loss, for example a program to plant tree orchards in or near communities.

A water monitoring research project should be implemented immediately to measure the impacts of afforestation on water availability (Brooks et al., 2003). Exotic plantations are believed to have major impacts on water availability and wetlands (Brooks et al., 2003). The forestry company should follow best management practices regarding water resource protection (e.g. maintaining riparian zones, planting tree species suitable to drought conditions). If water availability issues arise in communities the forestry company should have a response plan in place to provide water to communities in need.

\subsubsection{Recommendation 7: livelihood response program}

The issue of machamba relocation in the study area has already reached media attention (Aide, 2009). Therefore, it is recommended that relocation procedures be carefully drawn out so that if and when a family machamba is displaced for forestry develop- ment, the immediate response would ensure that the household is given adequate compensation (e.g. land, seeds, fertilizer, tools, labor) in a timely manner so that they can plant and cultivate their crops to provide adequate food and income for their households. Secondly, a trust fund should be set up to assist all of the households who may or have been displaced by forestry plantations. This trust fund could be used to set up a community outreach program and provide households with some guarantee in case of crop failure, and other disruptions as a result of plantations.

\subsection{Relevancy of FSC standard in addressing socio-economic impacts}

The international FSC standards cover sustainability issues in a generic sense and therefore the criteria and/or indicators in the standards do not address specific local issues. However, they can still be used to address the majority of potential socio-economic impacts outlined in this study. Notwithstanding, regional FSC standards could further address many of the potential socio-economic impacts that were outlined in this study by including the mitigation recommendations in their criteria and indicators.

Key areas to be addressed in a regional FSC standard should include the monitoring of wealth indicators, poverty alleviation and status, skills development and education, infrastructure, and indirect employment development. This would help determine whether or not forestry has helped alleviate poverty and has enhanced social and economic development. The FSC standard does not specify any requirements for community partnerships for conservation, sustainable agriculture or diversification of local economy. In a regional standard, these types of partnerships should be included as criterion. In addition, FSC participants should be required to have a community outreach program for impacts as a result of relocation, land changes, and health and wellness. A regional standard should also address the land tenure issues in Mozambique, to ensure communities are not left out of the land use decisions.

\section{Acknowledgement}

We would like to thank the UPM Forestry Company who funded the fellowship and first author's research study.

\section{References}

Adato, M., Meinzen-Dick, R., 2002. Assessing the Impact of Agricultural Research on Poverty Using the Sustainable Livelihoods Framework. FCND Discussion Paper 128. International Food Policy Research Centre.

Adhikari, B., Salvatore, D.F., Lovett, J.C., 2004. Household characteristics and forest dependency: evidence from common property forest management in Nepal. Ecological Economics 48, 245-257.

Aide, A., 2009. Mozambique: Pine Plantation Project Brings Misfortune to 31 Families in the North [Online]. Available at: http://www.wrm.org.uy/bulletin/141/ Mozambique.html (April 2009).

Akinnifesi, F.K., Sileshi, G., Ajayi, O.C., Chirwa, P.W., Mng'omba, S., Chakeredza, S. 2008. Managing bio-diversity of Miombo indigenous fruit trees for providing rural livelihoods in Southern Africa. Biodiversity 9, 72-74.

Bartlett, J.E., Kotrlik, J.W., Higgins, C.C., 2001. Organizational research: determining appropriate sample size in survey research. Information Technology, Learning, and Performance Journal 19, 43-50.

Boaler, S.B., Sciwale, K.C., 1966. Ecology of a Miombo Site, Lupa North Forest Reserve, Tanzania III: Effects on the Vegetation of Local Cultivation Practices. Redditch Development Corporation, Redditch, Worcester and Forests Division, Government of Tanzania.

Brooks, K., Folliott, P.F., Gregerson, H.M., Debano, L.F., 2003. Hydrology and the Management of Watersheds, 3rd ed. Wiley-Blackwell, Ames Iowa, 574pp.

Bryceson, D.F., 2002. The scramble in Africa: reorienting rural livelihoods. World Development 30, 725-739.

Buyck, B., 2008. The edible mushrooms of Madagascar: an evolving enigma. Economic Botany 62, 509-520.

Charnley, S., 2005. Industrial plantation forestry: do local communities benefit? Journal of Sustainable Forestry 21, 35-57. 
Chirwa, P.W., Syampungani, S., Geldenhuys, C., 2008. The ecology and management of the miombo eco-region for sustainable livelihoods in southern Africa: the case for non timber forest products. Southern Forests 70, 237-245.

Clement, F., Amezaga, J.M., 2009. Afforestation and forestry land allocation in northern Vietnam: analyzing the gap between policy intentions and outcomes. Land Use Policy 26, 458-470.

Cramer, C., Pontara, N., 1998. Rural poverty and poverty alleviation in Mozambique: what's missing from the debate? The Journal of Modern African Studies 36, 101-138.

Cuellar, M., Mikael, R., Ferrao, C., 2006. Lichinga Field Study: Linkages Between Livelihoods and Natural Resources. SIDA's EIA Helpdesk. Orgut (July 2006).

Davidson, J., 1995. Ecological aspects of eucalypt plantations. In: White, K., Ball, J., Kashio, M. (Eds.), Proceedings, Regional Expert Consultation on Eucalyptus, vol. I. RAP Publication, 202 pp.

Dougnac, S., 2008. Personnel Interview. Lichinga, Mozambique (June).

Ellis, F., 2003. Livelihoods and rural poverty reduction in Uganda. World Development 31, 997-1013.

Evans, J., Turnbull, J.W., 2000. Plantation Forestry in the Tropics: The Role, Silviculture, and Use of Planted Forests for Industrial, Social, Environmental, and Agroforestry Purposes, 3rd ed. Oxford University Press, Oxford, 488 pp.

Ferraz, B., Munslow, B., 1999. Sustainable Development in Mozambique. Africa World Press, Asmara, 242 pp.

Forestal Oriental, 2006. Environmental impact assessment: Aspectos económicos y sociales. Forestal Oriental, Uruguay.

FSC, 1996. FSC International Standard: FSC Principles and Criteria for Forest Stewardship. FSC-STD-01-001 (Version 4.0). Forest Stewardship Council A.C. Last Amended in 2002 [Online]. Available at: http://www.fao.org (11.07.09).

Geldenhuys, C.J., 2005. Basic Guidelines for Silvicultural and Management Practices in Mozambique. Report FW-04/05. FORESTWOOD cc, Pretoria, 78 pp.

Heaton, K., 2005. Mitigating environmental and social impacts of intensive plantation forestry. Journal of Sustainable Forestry 21, 75-96.

Instituto Nacional de Estatistica (Niassa), 2007. Anuário Estatístico 2007: Província de Niassa. Delegação Provincial de Niassa, Mozambique (Mozambique Census Report).

Irish Aid, 2007. Rural Development and Agriculture [Online]. Available at: http:// www.irishaid gov.ie/development_agriculture.asp (25.01.09).

Kruskal, W., Wallis, W.A., 1952. Use of ranks in one-criterion variance analysis. Journal of American Statistical Association 47 (260), 583-621.

Kumar, N., Saxena, N., Alagh, Y., Mitra, K., 2000. India: Alleviating Poverty Through Forest Development. The World Bank (OED). Evaluation Country Case Study Series. World Bank, Washington, DC, 195 pp.

Landry, J., 2009. Analysis of the potential socio-economic impacts of establishing plantation forestry on rural communities in Sanga District, Niassa Province, Mozambique. MSc Thesis. Department of Forestry and Wood Science, Stellenbosch University.

Manhiça, B., 2008. Personnel Interview. Lichinga, Mozambique (October).

Mann, H.B., Whitney, D.R., 1947. On a test whether one of two random variables is stochastically larger than the other. Annuals of Mathematical Statistics 18 , 50-60.
Maung, T.M., Yamamoto, M., 2008. Exploring the socio-economic situation of plantation villagers: a case study in Myanmar Bago Yoma. Small Scale Forestry 7 29-48.

Ministério da Administração Estatal, 2005. Prefil do districto de mecanhelas provincial de Niassa [Online]. Available at: http://www.govnet.gov.mz/ (12.07.08).

Nhantumbo, I., Dent, J.B., Kowero, G., 2001. Goal programming: application in the management of miombo woodland in Mozambique. European Journal of Operational Research 133, 310-322.

Place, F., Adato, M., Hebinck, P., Omosa, M., 2003. The Impact of Agroforestry-based Soil Fertility Replenishment Practices on the Poor in Kenya. FCND Discussion Paper No. 160. International Food Policy Research Institute.

Pontara, N., 2001. Gender and Poverty in Mozambique: A Review of Empirical Literature (Draft) [Online]. Available at: http://www.ilo.org/public/../ fop_workshop_lit_review_empirical.doc (3.04.09).

Race, D., Desmond, H., 2001. Forestry Out-grower Schemes: A Global View. Forestry Department, FAO, Rome, 20 pp.

Ramadhani, T., Otsyina, R., Franzel, S., 2002. Improving household incomes and reducing deforestation using rotational woodlots in Tabora district, Tanzania. Agriculture, Ecosystems, and Environment. 89, 229-239.

Salomão, A., Matose, F., 2007. Towards Community Based Forest Management of Miombo Woodlands in Mozambique [Online]. Available at: http://www.cifor org/miombo/docs/CBNRMMozambique1207.pdf (17.09.08).

Schirmer, J., 2006. Socio Economic Impacts of Land Use Change to Plantation Forestry: A Review of Current Knowledge and Case Studies of Australian Experience [Online]. Available at: http://www.ces.ncsu.edu/nreos/forest/feop/ Agenda2006/iufro_plantations/proceedings/G01 m-Schirmer.pdf (23.03.08).

Scoones, I., 1998. Sustainable Rural Livelihoods: A Framework for Analysis. IDS Working Paper 72.

Sokal, R.R., Rohlf, F.J., 1994. Biometry: The Principle and Practice of Statistics in Biological Research, 3rd ed. Freeman, New York, 887 pp.

Suca, A., 2001. Land reform in SADC region - Mozambique land reform and poverty alleviation. In: Unpublished Paper Delivered at the SARPN Conference, Pretoria, 4-5 June.

Strang, R.M., 1974. Some man-made changes in successional trends on the Rhodesian highveld. Journal of Applied Ecology 111, 249-263.

Syampungani, S., 2008. Vegetation change analysis and ecological recovery of the Copperbelt miombo woodlands of Zambia. PhD Thesis. University of Stellenbosch, Stellenbosch.

Tonts, M., Campbell, C., Black, A., 2001. Socio-economic Impacts of Farm Forestry. A Report for the RIRDC/LWRRDC/FWPRDC Joint Venture Agroforestry Project. RIDC Publication No. 01/45. RIDC Project No. ECU-8A.

Tschirley, D.L., Benfica, R., 2001. Smallholder agriculture, wage labour and rura poverty alleviation in land - abundant areas of Africa: evidence from Mozambique. The Journal of Modern African Studies 39, 333-358.

World Bank, 2008. Mozambique Beating the Odds: Sustaining Inclusion in a Growing Economy, a Mozambique Poverty, Gender, and Social Assessment. Volume 1: Main Report. Report No. 40048-MZ (February 2008). 